\title{
Ginecomastia ca Semn de Prezentare Într-o Tumoră Testiculară Prezentare de $\mathrm{Caz}$
}

\section{Cristina Corina Pop Radu*}

Disciplina de Endocrinologie; Universitatea de Medicină și Farmacie, Târgu Mureş, Romania

"Corresponding author: Cristina Corina Pop Radu, MD, Disciplina de Endocrinologie; Universitatea de Medicina si Farmacie, Târgu Mures, Str. Gh. Marinescu, No 38, 540139, Târgu Mureș, Romania, Tel: +40 (0) 2652144 10/236; Fax +40 (0) 7446471 72; E-mail: ccorinaradu@yahoo.com

Received date: 16 December 2013; Accepted date: 27 December 2013; Published date: 9 May 2014

Copyright: @ 2014 Pop Radu CC This is an open-access article distributed under the terms of the Creative Commons Attribution License, which permits unrestricted use, distribution, and reproduction in any medium, provided the original author(s) and source are credited.

\begin{abstract}
Background: Orchitis tumor incidence is rare, about $2 \%$ of male malignancies. The pathology of tumoral orchitis has a maximum incidence between the ages $20-35$, in children being more frequent the embryonal carcinoma and teratoma, in adult are met all types and in elderly predominates the seminoma. About $25 \%$ has endocrine secretory capacity. The incidence of gynaecomastia in adult men is reported as being $35-65 \%$, depending on the criteria for diagnosing gynaecomastia and the age group. However, only $2 \%$ of men presenting with gynaecomastia are founded to have testicular tumours.
\end{abstract}

Case Report: We present the case of a 27 years old patient, diagnosed two years ago with testicular tumor. In diagnosis, the first sign was the unilateral gynaecomastia then neoplastic transformation of the left testicle was noted. The diagnosis was confirmed by ultrasound exam and tumoral markers ( $\beta$ human chorionic gonadotrophin over $5000 \mathrm{mUI} / \mathrm{mL}$; alpha-fetoprotein at $12.3 \mathrm{UI} / \mathrm{mL}$; lactate dehydrogenase at $1840 \mathrm{U} / \mathrm{L}$ ). Left orchiectomy was performed. The pathological report showed a mixed tumor with germinal cells: embryonal carcinoma, teratoma and choriocarcinoma. The patient refuse adjuvant therapy and two months postoperatively pulmonary and vertebral metastasis were revealed. He followed radiotherapy, chemotherapy and neurosurgical treatment with complete remission.

Conclusion: We emphasize the importance of complete physical exam and testicular ultrasonography in any case of suspicion of testicular tumor. The multidisciplinary approach and treatment allows good results in advanced testicular tumors.

Keywords: Testicular Tumor; Paraneoplastic Gynecomastia

\section{Introducere}

Cancerul testicular are o incidență de $2 \%$ în oncologia generală masculină, ocupând locul patru între cancerele genito-urinare la bărbat și reprezentând cea mai frecventă neoplazie a adultului tânăr între 15-40 de ani (exceptând hemopatiile), fiind responsabil de o treime din decesele acestui grup de vârstă. Incidența este de 3-6 cazuri noi la 100.000 de bărbați/an, cu o tendință globală de creștere în ultimii ani în special la rasa albă (incidența maximă în SUA și Danemarca), în Asia şi Africa incidența bolii fiind extrem de mică. La copii se întâlnește mai frecvent carcinomul embrionar (CE) şi teratomul, la adult toate formele, iar la vârstnic predomină seminomul. Aproximativ $25 \%$ posedă capacitate secretorie endocrină. Tumorile celulelor germinale (TCG) reprezintă aproape 95\% din tumorile primare testiculare. Se împart în tumori seminomatoase (45\%) şi non-seminomatoase (50\%). Dintre cele nonseminomatoase (TCGNS) cele mixte sunt cele mai frecvente (40\%). Teratoamele şi terato-carcinoamele constituie 30\% din leziunile non-seminomatoase. CE pur este relativ rar (20\%). Choriocarcinomul (ChC) este cel mai rar (1\%), dar și cel mai letal tip tumoral non-seminomatos [1]. Ginecomastia reprezintă un semn de activitate endocrină, incidența ei la bărbații adulți fiind de 35-65\%, în funcție de criteriile de diagnostic și grupa de vârstă studiată. Totuși, doar $2 \%$ până la $11 \%$ a pacienților cu carcinom testicular se prezintă inițial cu ginecomastie $[2,3]$.

\section{Prezentare De Caz}

Prezentăm un pacient în vârstă de 27 ani, care s-a adresat Serviciului de endocrinologie pentru apariţia unei formaţiuni tumorale la nivelul sânului drept de cca 7 luni. La examenul clinic s-a constatat retroareolar mamar drept, țesut glandular mamar de cca $3 \times 2 \mathrm{~cm}$, nedureros, mobil față de țesuturile supra- și subiacente, fără adenopatii axilare; testicul stâng mărit, cu suprafață neregulată, deformată, dur, nedureros (clasicul "testicul greu"). Fără alte modificări clinice obiective. Anamnestic relatează apariția ginecomastiei în urmă cu 3 luni și creșterea în volum dureroasă, însoțită de fenomene inflamatorii a testiculului și hemiscrotului stâng cu o lună anterior prezentării la consultul endocrin. Ecografia mamară (Figure 1) a evidențiat în sânul drept un placard lenticular de țesut glandular mamar cu dimensiuni de $3,2 \times 2 \mathrm{~cm}$ confirmând ginecomastia unilaterală dreaptă. Ecografia testiculară (Figure 2) a evidențiat un testicul stâng hipertrofiat (cca 8 $\mathrm{cm}$ ), cu structură total dezorganizată, foarte inomogenă, cu aspect polichistic.

Explorările de laborator au evidențiat nivele mult crescute ale AlfaFetoproteina (AFP), gonadotrofinei corionice umane (beta HCG, BHCG), antigenului carcinoembrionar (ACE) şi lactat-dehidrogenazei (LDH) (Table 1).

Computer tomografia a confirmat leziunea testiculară și a evidențiat perivezical și periseminal câțiva noduli adenopatici cu diametru de 4-5 $\mathrm{mm}$, dar fără adenopatie retroperitoneală. 


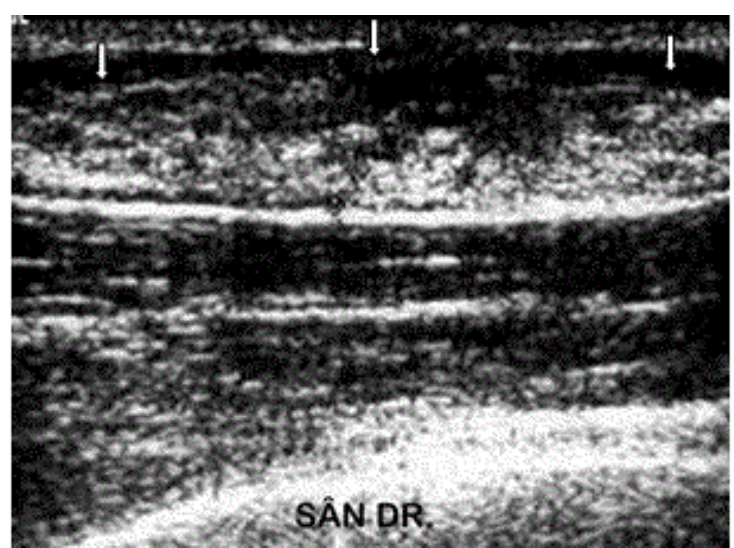

Figure 1: Ecografia mamară.

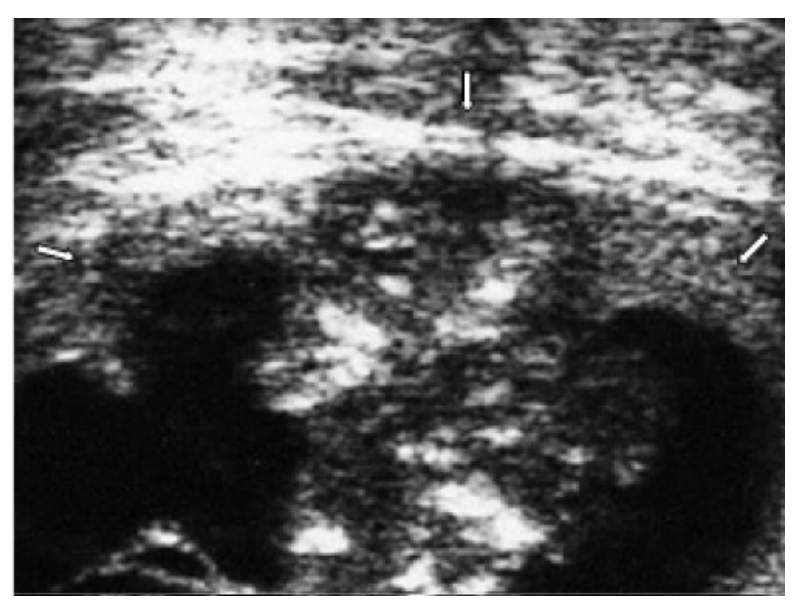

Figure 2: Ecografia testiculului stâng.

Tumora a fost considerată în stadiul III și s-a realizat orhietcomia stângă urmând ca tratamentul să fie completat cu chimio- şi radioterapie.

Examenul histopatologic a evidențiat macroscopic: piesă de orhiectomie de $80 \times 50 \times 45 \mathrm{~mm}$ cu funicul spermatic de $30 \times 10 \mathrm{~mm}$. Pe secțiune se remarcă o formațiune tumorală care înlocuiește aproape $90 \%$ din parenchimul testicular. Tumora are o culoare alb-cenușie cu multiple zone chistice. Examinarea microscopică a evidențiat o tumoră mixtă cu mai multe componente: choriocarcinom 20\%, carcinom embrionar $40 \%$ şi teratom $40 \%$ (Figure 3). Aspectul microscopic de teratom a fost confirmat de prezența de epitelii glandulare înconjurate de țesut conjunctiv și țesut neted (teratom matur), precum şi zone de teratom imatur, cu epitelii de tip embrionar înconjurate de o stromă mixomatoasă.

Postoperator pacientul refuză tratamentul adjuvant, iar la două luni postoperator acuză scădere ponderală și dureri toraco-lombare care ulterior au devenit insuportabile și s-au complicat cu instalarea parezei membrului inferior stâng. Pacientul se internează în Institutul Național de Oncologie Budapesta unde se decelează nivele mult crescute de BHCG (>10.000 mUI/mL), se efectuează rezonanța magnetică nucleară $(\mathrm{RMN})$ de coloană vertebrală și torace, care evidențiază diseminare pulmonară multiplă și metastazare la nivelul vertebrei toracice VIII (Figure 4).

Ulterior a fost supus unei cure chimioterapice: $4 \times \mathrm{BEP}$ (Bleomicină, Etoposid, Cisplatin), cu administrarea la 4 luni de Carboplatin 700mg şi Etoposid $180 \mathrm{mg}$. S-a efectuat iradiere cu $80 \mathrm{~Gy}$ pe segmentul afectat al coloanei vertebrale și după o ameliorare temporară a reapărut pareza la ambele membre inferioare care a impus efectuarea laminectomiei în scop de decompresie.

\section{Discuții}

Practic 95-97\% din tumorile testiculare sunt maligne și germinale, astfel încât vechiul principiu clinic, conform căruia orice tumoră scrotală solidă trebuie considerată cancer testicular germinal până la proba contrarie, rămâne actual. De obicei se prezintă ca o masă unilaterală nedureroasă localizată în scrot. În aproximativ 20\% din cazuri, primul simptom este durerea scrotală. În $10 \%$ din cazuri, cancerul testicular poate imita orhiepididimita, $\mathrm{cu}$ o întârziere consecutivă în stabilirea diagnosticului corect [4]. Demn de remarcat sub raport clinic este faptul că, descoperită în stadiu local franc tumoral, boala este în mod real în stadiu diseminat cu foarte rare excepții [4]. Netratată, boala duce inexorabil - fără remisiuni spontane sau accidente evolutive imprevizibile - la deces în primii doi ani de evoluție, moartea producându-se aproape întotdeauna datorită metastazelor pulmonare.

$\mathrm{ChC}$ are un indice de malignitate foarte crescut (practic incurabil), secretă BHCG, incidența maximă este între 15-35 ani, fiind foarte rar în forma pură. Se asociază cu ginecomastie bilaterală, asociată sau nu de creșterea AFP (markerul CE) şi a hormonului lactogen placentar. Hiperproducția de BHCG induce creșterea de estrogeni, dar nu și de testosteron. Sunt tumori moi, mici, hemoragice, rapid metastazante. Microscopic este format din sinciţiotrofoblaști și citotrofoblasti dispuși sub formă papilară [1]. Datorită agresivității sale deosebite, ChC înregistrează un curs rapid fatal prin hemoptizie masivă, deși adesea leziunea primară testiculară rămâne "ocultă" chiar la examenul piesei operatorii (leziune mică sau chiar "burned out tumor") [1,5].

CE reprezintă aproximativ 25\% din tumorile testiculare, având incidența maximă la pacienții mai tineri. Macroscopic este o tumoră mai mică, cu suprafața neregulată prin consistența inegală, dezvoltată în plin parenchim testicular. Pe secțiune are aspect neomogen, alb cenuşiu, cu zone întinse de necroză hemoragică. Pattern-ul microscopic include o mare varietate de celule epiteliale dispuse glandular papilar, cu caracter anaplastic, cu structură embrionară heterogenă. Este foarte agresiv [1,4].

Examenul de control la 6 luni de la chimioterapie arată absența ginecomastiei şi parapareză în remisiune. Dozările hormonale nu au evidențiat disfuncții endocrine, cu excepția unui nivel ușor crescut de FSH explicabil în urma tratamentelor (FSH: $23,798 \mathrm{mUI} / \mathrm{mL}$ $(2,1-18,6))$; markerii tumorali erau de asemenea în limite normale. Imagistica evidențiază regresia leziunilor secundare și un aspect normal al testiculului drept. Pacientul este considerat în remisiune și se continuă monitorizarea prin serviciul de oncologie.

Teratomul are o incidență mică în forma pură, fiind mai frecvent asociat CE (teratocarcinom). Macroscopic prezintă pe secțiune un aspect neomogen, pestriț, cu arii chistice, solide, cartilaginoase, osoase, sebacee, mucoase etc. Microscopic prezintă multiple structuri celulare specifice originii: glande mucoase (endoderm), țesut cartilaginos, muşchi (mezoderm), chisturi epiteliale scuamoase (ectoderm) cu 
Citation: Pop Radu CC. Ginecomastia ca Semn de Prezentare Într-o Tumoră Testiculară Prezentare de Caz. Journal of Surgery [Jurnalul de Chirurgie] 2014; 10(1): 87-91. doi:10.7438/1584-9341-10-1-18

Page 89

Table I: Markerii tumorali serici pre- și post-operator; AFP alfa-feto-proteina; BHCG gonadotrofina corionică umană; ACE antigen carcinoembrionar; LDH lactat dehidrogenaza.

\begin{tabular}{|l|l|l|l|l|}
\hline & Preoperator & 1 lună postoperator & 4 luni postoperator & Valori normale \\
\hline AFP & 12,3 & 1,0 & 0,770 & $<7 \mathrm{Ul} / \mathrm{mL}$ \\
\hline BHCG & $>5000$ & 1000 & $>10.000$ & $<2,5 \mathrm{mUl} / \mathrm{mL}$ \\
\hline ACE & 20 & 6,7 & & $<3,4 \mathrm{ng} / \mathrm{mL}$ \\
\hline LDH & 1840 & 490 & & $230-460 \mathrm{U} / \mathrm{L}$ \\
\hline
\end{tabular}

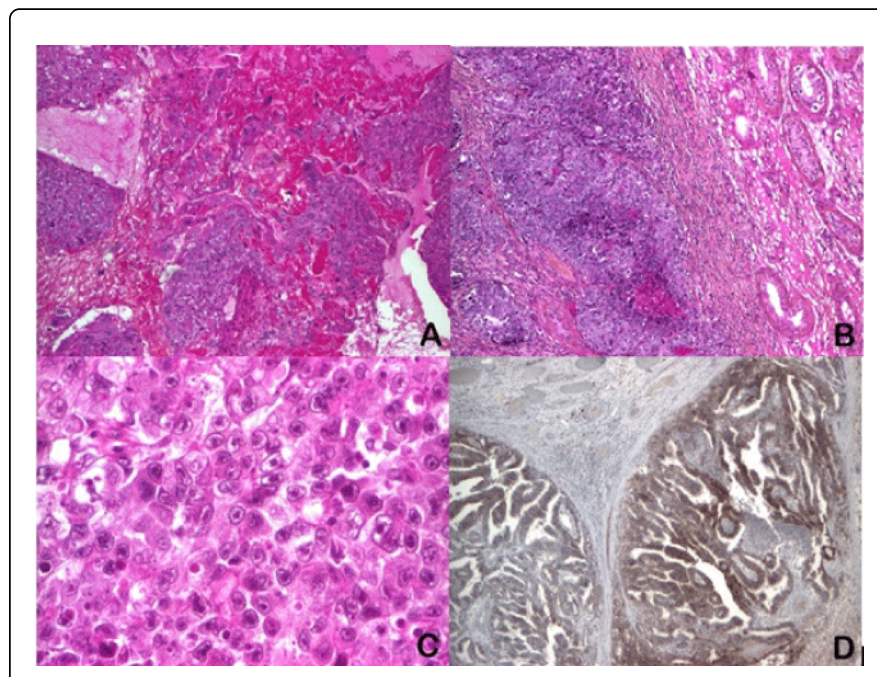

Figure 3: Examenul histopatologic: nu se observă celule tumorale în vasele capsule; tumora prezintă mai multe componente de: (A) Choriocarcinom - 20\%, spații vasculare și zone de necroză delimitate de sincițio- și cito-trofoblaști; (B) și (C) Carcinom embrionar - 40\%, arhitectură papilară și tubulară, celulele au limite imprecise, nuclei măriți în volum, cu nucleoli vizibili, numeroase mitoze și zone de necroze. IGCNU în tubii seminiferi restanți (B). Imunohistochimic (D) zonele de carcinom embrionar exprimă CD 30 și sunt negative la AFP.

diferite grade de diferențiere: matur, imatur, cancerizat. Este mai putin agresiv, cu potențial metastazant mai redus. Forma pură nu raspunde la chimioterapie $[1,4]$.

Teratomul și CE metastazează preponderent pe cale limfatică, iar ChC preponderent hematogen. Metastazele viscerale se produc în plămân (cel mai frecvent), ficat, oase, creier.

TCG pot metastaza cu altă structură histologică decât cea primară (în forma pură sau asociată), metastazele având capacitatea de a se transforma - spontan sau postcitostatic - într-o altă neoplazie (cel mai frecvent în sarcom) $[1,4,6]$.

O treime din pacienții cu TCG se prezintă la momentul diagnosticului inițial în stadii diseminate de boală, cu metastaze limfoganglionare retroperitoneale sau viscerale [4].

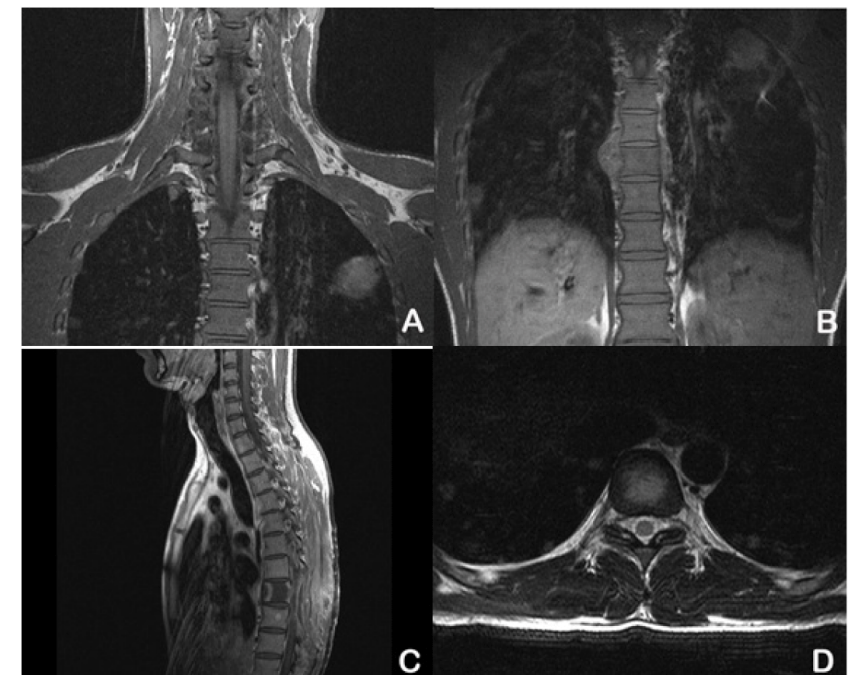

Figure 4: Imagistică prin rezonanță magnetică toracică şi de coloană vertebrală: (A) și (B) Diseminare pulmonară multiplă; (B) (C) şi (D) Corpul vertebrei T VIII cu modificări structurale patologice la nivelul întregului corp vertebral (aspect de metastază). Tumoră epidurală și extra-osoasă cu o extindere semnificativă, cu compresia măduvei spinării. La nivelul T IX formațiune patologică de dimensiuni mici cu densitate patologică (metastază).

Cauzele principale pentru întârzierea diagnosticului sunt: simptomatologia locală relativ nespecifică; lipsa de examinare a scrotului la examenul clinic de rutin (falsă pudoare); ignoranța și sentimentul de culpabilitate al pacientului care leagă leziunea scrotală de o falsă boală venerică.

Incidența ginecomastiei la bărbații adulți este raportată la 35-65\%, în funcție de criteriile de diagnostic și grupa de vârstă studiată. Totuși, doar $2-11 \%$ a pacienților cu carcinom testicular se prezintă inițial cu ginecomastie $[2,3]$.

Ginecomastia reprezintă un semn de activitate endocrină, poate fi uni- sau bilaterală, poate preceda prezența tumorii testiculare palpabile sau tulburările hormonale și apare în cazul ChC, $\mathrm{CE}$, tumori cu celule Sertoli, tumori cu celule Leydig după vârsta de 30 de ani. Ginecomastia este de obicei atribuită dezechilibrului dintre estrogeni și androgeni, 
dar poate fi datorată în parte și acțiunii directe a LH-ului (hormon luteinizant) și HCG-ului la nivelul sânului [3,7-10].

Markerii tumorali serici, AFP, BHCG și LDH contribuie la diagnostic și stadializare, rolul lor major fiind în protocolul de urmărire, dinamica evoluției lor sub tratament reprezentând un indicator extrem de sensibil în aprecierea răspunsului terapeutic. Totuşi nivele serice normale ale acestor markeri nu exclud diagnosticul de TCG. În general, o creștere a acestor markeri apare în $51 \%$ a cazurilor de TCG. Timpul mediu de înjumătățire plasmatică este de 5-7 zile pentru AFP și de 2-3 zile pentru HCG [4]. Nivelele de AFP și BHCG sunt crescute la $50-70 \%$, respectiv $40-60 \%$ a pacienților cu TCG non-seminomatoase. LDH este un marker mai puțin specific, nivelul său fiind proporțional cu volumul tumoral. Cei mai fiabili și utilizați în practică sunt AFP, BHCG și gonadotrofina urinară totală. Specificitatea lor este maximă, iar sensibilitatea lor globală înregistrează 75\% pentru AFP și 51\% pentru BHCG. Cele mai mari nivele sunt atinse în ChC. Sensibilitatea metodei crește cu stadiul de boală. Radio-imuno-dozarea HCG în urina/24 de ore pare mai fidelă decât determinarea serică. Persistența nivelelor crescute ale markerilor serici după orhiectomie indică prezența bolii metastatice, dar normalizarea acestora nu exclude prezența metastazelor [4,6]. Markeri citogenetici și moleculari sunt disponibili doar în centre specifice $\mathrm{cu}$ scop de cercetare.

Factorii de risc pentru dezvoltarea cancerului testicular sunt istoricul de criptorhidie sau testicul necoborât (cel mai important factor de risc cunoscut), sindromul Klinefelter, istoricul familial de cancer testicular la rudele de gradul I (tată sau frați; studii cito-genetice ale materialului tumoral germinal au relevat prezența izocromozomului (12 p) al brațului scurt al cromozomului 12 în $80 \%$ din cazuri, justificând eticheta de marker diagnostic), prezența cancerului testicular în antecedente (risc de 500 de ori mai mare față de populația masculină normală), infertilitatea, expunere la DDT (pesticid organo-clorurat), atrofia testiculară (secundară orhitei urliene sau torsiunii de funicul spermatic - risc de 20 ori mai mare), hernie inghinală în copilărie, rasa albă, deficitul de 21-hidroxilaza, hipertonia de ACTH, administrarea de estrogeni mamei pe parcursul sarcinii. [4]

Diagnosticul diferențial se face cu tumefacții scrotale dureroase: orhiepididimita acută nespecifică, epididimita cronică nodulară, orhita granulomatoasă, torsiunea de funicul spermatic sau hidatida Morgagni (frecvente la copil); tumoră inghino-scrotală încarcerată sau strangulată; tumefacții scrotale nedureroase: hidrocel, hematocel, spermatocel, chist epididimar, varicocel, periorhită nodulară; tumori paratesticulare: tumori maligne sau benigne de epididim sau funicul spermatic. Forme clinice responsabile de erori de diagnostic sunt hidrocelul satelit tumorii în $10 \%$ din cazuri și "masca clinică" pseudoinflamatorie în $30 \%$ din cazuri [4].

Chimioterapia adjuvantă are meritul de a fi crescut curabilitatea globală a neoplaziei de la $35 \%$ (anii '70) la $95 \%$ în prezent. Este utilizată polichimioterapia, în cure de inducție, administrate la intervale de 3-4 săptămâni, în funcție de volumul tumorii metastatice (2-4 cure). Regimurile citostatice combină droguri foarte eficiente: cisplatin, bleomicina, actinomicina $\mathrm{D}$, vinblastina, ciclofosfamida, methotrexat, etoposid şi derivate mai puțin toxice și mai active: carboplatin, isofosfamida [11].

Monitorizarea răspunsului terapeutic presupune reevaluare stadială frecventă: determinarea markerilor (lunar), radiografie toracică (la 2 luni în primii 2 ani, la 4 luni în al 3-lea an și la fiecare 6 luni în anii 4 și
5), computer tomografie abdomino-pelvină, la nevoie toracică (la 3, 6, 9 și 12 luni) de la terminarea tratamentului, chiar și în caz de răspuns complet. Răspunsul incomplet obligă la reevaluarea factorilor diagnostici/prognostici inițiali și amplificarea schemei de tratament prin introducerea de modalități terapeutice mai agresive, "de salvare".

Protocoalele moderne de diagnostic, tratament și urmărire au făcut ca rata supraviețuirii cancer-free la 5 ani să atingă $100 \%$ pentru stadiul de boala locală și $70-95 \%$ pentru stadiile de boală diseminată incipientă și moderată $[4,6,11]$.

Tratamentul și prognosticul cancerului testicular depinde într-o mare măsură de tipul histologic și stadiul clinic. În concordanță cu criteriile International Germ Cell Cancer Collaborative Group (IGCCCG) risk classification $[4,11]$, pacientul nostru a fost încadrat iniţial în grupul cu prognostic intermediar (tumoră nonseminomatoasă, localizare primară în testicul-spațiu retroperitoneal, BHCG >5000, LDH > 500, făă metastaze cerebrale, hepatice sau osoase) cu o rată de supraviețuire la 5 ani de $80 \%$. Totuși, prezența componentei de choriocarcinom (20\%), subtipul histologic cel mai agresiv cu metastazare rapidă hematogenă determină un prognostic nefavorabil. Prezența carcinomului embrionar (40\%) și a teratomului (40\%) sunt de asemenea elemente de prognostic nefavorabil fiind asociate cu tendință de metastazare. Un alt factor important care contribuie semnificativ la vindecare este tratamentul complet și monitorizarea corectă, regulată a pacientului. În cazul pacientului prezentat întârzierea intervenției chirurgicale (din motive personale), ulterior refuzarea chimioterapiei postoperator cu o pauză de tratament de 4-5 luni au fost elemente care au contribuit la apariția complicațiilor (diseminare pulmonară și metastazare la nivelul coloanei vertebrale cu parapareză) și implicit la un prognostic nefavorabil (supraviețuire generală la 5 ani estimată la 48\%).

\section{Concluzii}

Cazul prezentat se constituie într-un argument pentru importanța examenului clinic complet și corect, în particular, examinarea testiculară la bărbații cu ginecomastie. În caz de suspiciune este de preferat efectuarea ecografiei testiculare, chiar în absența modificărilor clinice și determinarea markerilor serici (AFP și BHCG).

\section{Conflict De Interese}

Autoarea nu declară nici un conflict de interese.

\section{Bibliografie}

1. Ulbright TM (2005) Germ cell tumors of the gonads: a selective review emphasizing problems in differential diagnosis, newly appreciated, and controversial issues. Mod Pathol 18 Suppl 2: S61-79.

2. Daniels IR, Layer GT (2003) Testicular tumours presenting as gynaecomastia. Eur J Surg Oncol 29: 437-439.

3. Burgu B, Aydogdu O, Telli O, Kankaya D, Soygur T, et al. (2011) An unusual cause of infantile gynecomastia: sertoli cell tumor. J Pediatr Hematol Oncol 33: 238-240.

4. Shin YS, Kim HJ (2013) Current management of testicular cancer. Korean J Urol 54: 2-10.

5. Balzer BL, Ulbright TM (2006) Spontaneous regression of testicular germ cell tumors: an analysis of 42 cases. Am J Surg Pathol 30: 858-865.

6. Stamatiou K, Papadopoulos P, Perlepes G, Galariotis N, Olympitis M, et al. (2009) Mixed germ cell tumor of the testicle with ravdomuosarcomatous component: a case report. Cases J 2: 9299. 
7. Carlson HE, Kane P, Lei ZM, Li X, Rao CV (2004) Presence of luteinizing hormone/human chorionic gonadotropin receptors in male breast tissues. J Clin Endocrinol Metab 89: 4119-4123.

8. Hassan HC, Cullen IM, Casey RG, Rogers E (2008) Gynaecomastia: an endocrine manifestation of testicular cancer. Andrologia 40: 152-157.

9. Harris M, Rizvi S, Hindmarsh J, Bryan R (2006) Testicular tumour presenting as gynaecomastia. BMJ 332: 837.
10. Johnson RE, Murad MH (2009) Gynecomastia: pathophysiology, evaluation, and management. Mayo Clin Proc 84: 1010-1015.

11. International Germ Cell Consensus Classification: a prognostic factorbased staging system for metastatic germ cell cancers (1997). International Germ Cell Cancer Collaborative Group. J Clin Oncol 15: 594-603. 